INTERNATIONAL JOURNAL OF RESEARCHES IN BIOSCIENCES, AGRICULTURE AND TECHNOLOGY (c) VISHWASHANTI MULTIPURPOSE SOCIETY (Global Peace Multipurpose Society) R. No. MH-659/13(N) WwW.vmsindia.org

\title{
NUTRITIONAL AND ANTIOXIDANTS STATUS OF (AVERRHOA CARAMBOLA LINN.)
}

\section{Rajendra Pati1 ${ }^{1}$ and Minakshi Mahajan ${ }^{2}$}

${ }^{1}$ Amolakchand Mahavidyalaya Yawatmal

${ }^{2}$ Fergusson College, Pune-4.

\section{ABSTRACT}

Naturally occurring sources of the plants are rich in antioxidants. Averrhoea Carambola Linn (Oxalidaceae), Kamrakh is an evergreen tree. Fruits are long, watery, translucent, fragrant $\&$ of a rich amber or golden yellow colour. When green they are astringent, but on ripening de velop a sweetish acid tas te. The fruits are made in to stews, curries, puddings \& tarts. The slight unripe ones are made into jams, jellies, pickles and preserves. The present study was planned for knowing the nutritional ele ments and non enzymatic antioxidants (ascorbic acid, phenol, sugar, proteins) were estimated from the fruits. The results are focused on good amount of ascorbic acid (Vit C) due to which fruits are often used for making refreshing drink and for cleaning metal surfaces, es pecially for removing rust stains.

Keywords: Kamrakh, nutritional and non enzymatic antioxidants.

\section{Introduction:-}

Evidences show use of plants of primitive or ethnic populations in the age of Rig veda. Tribal knowledge of plants is important not just for the tribal people themselves but for the wider world. Many plants recognized as a medicine in earlier days provided valuable drugs in modern meidicne. Maximum no. of papers are being published on the aspect of indigenous herbs in he alth under various titles such as herbal drugs, herbal medicines, phyto the rapy, folk medicines, medicinal herbs, traditional medicines etc. Ocimum Sanctum (Tulsi), ficus bengalensis (Val) Aegle marmelos (Bel), Saraca indica (Ashoka tree). And many other species have been anciently described as plants which render several protective health bene fits (Mitra R, 1997)

Oxygen free radical induced cellular damages in pathobiological conditions including malignancies, bacterial \& parasitic infections, lung damage, inflammatory diseases reperfusion injury cerebrovascular damage, athero scle rosis and aging (Nadkarni G.D, Mitra A.G, Deshpande U.R and Pahuja D.N, 1991) A delicate balance of cellular antioxidant de fense sys te $m$ is essential to protect the body against oxidative stress (Ray S and Chakraborty $\mathrm{P}, 1999$ ).

There are heterozygous groups of chemicals which have been found to control oxidant damage to plants, mainly by the inhibition of oxidative processes. These include simple redu cing agents, comme rcial antioxid ants $\&$ specific antioxidants used in the rubber industry. Antioxidants are more significant in fruits and leafy vegetables.

Many kinds of $\begin{aligned} & \text { antioxidative } \\ & \text { polyphenolic }\end{aligned}$
$\begin{aligned} & \text { componentsthat contain } \\ & \text { compounds, chlorophylls, }\end{aligned}$ carotenoids,
tocopherol derivatives, lignan, and
relatedisoprenoids have been isolated from
different kinds of plants, such as oilseeds, cereal

crop, vegetables, leaves, roots, spices, herbs, and seaweeds, for use as antioxidants (Wettasinghe and Shahidi, 1999, Gulcin 2006b).

Polyphenolic compounds not only effectively prevent the oxidation of foods but they also act as a protective factor against oxidative damage in the human body (Castillo and et al., 2000; Lope $z$ Amoros and et al., 2006).

Sara Jelodarian and et.al. (2012) worked on evaluation of antioxidant activity of fruit Malus domestica. Tenderstage and mature stage of leaves arealso great source of antioxidants (Minakshi Mahajan \& Monali Patil (2004).

Averrhoa Carambola Linn is a small hand some eve rgreen tree 15-30 high with flowe rs springing from the bark, and acutely five angled ovoid fruits 3-4" long, watery translucent, fragrant and of a rich amber or golden yellow colour.

\section{Material and Method:-}

Fresh fruits are collected from naturally grown plants in Botanical garden of Fergusson College. They were rinsed in to $\mathrm{p}$ water to remove any adherent impurities \& blotted gently be tween tissues paper folds to remove any remaining water droplets. Then the fruits were weighed $\&$ used for the analysis of the various parame ters.

Nutritional, enzymic \& non enzymic antioxidant status of fruits were analysed.

The parameters are analysed at ripen $\&$ unripen fruiting stage. The enzymic, non enzymic, non enzymic \& organic constituents were analysed by-

Enzymic antioxidants-

Catalase (Luck H., 1974)

Peroxidase (Vidyasekharan and Durairaj, 1973) polyphenol oxidase (Vidyasekharan and Durairaj, 1973).

Non enzymic antioxidants are 
Ascorbic acid (Sadasivan and Theymoli Balasubrame nan,1987)

Polyphe nols (Farkas and Kiraly, 1962)

Reducing sugar (Nelson, 1944)

Starch (Sadashivam and Manikam, 1966) proteins (Lowry e tal.,1951).

Enzymic and non-enzmic oxidants organic constituents in Averrhoa carambola Linn.

\begin{tabular}{|l|l|l|}
\hline Parameters & $\begin{array}{l}\text { Unripe } \\
\text { fruits }\end{array}$ & $\begin{array}{l}\text { Ripe } \\
\text { fruits }\end{array}$ \\
\hline Catalase (units $\mathrm{min}^{-1} \mathrm{~g}^{-1}$ ) & 120 & 195 \\
\hline Peroxidase (Units /g) & 2.25 & 3.25 \\
\hline Polyphenol oxidase (Units /g) & 1.01 & 2.25 \\
\hline Ascorbic acid (mg/g) & 7.24 & 9.85 \\
\hline Polyphenols (mg/g) & 16.58 & 24.58 \\
\hline
\end{tabular}

Catalase, 1 Unit = amount of enzyme required to decrease the absorbance by 0.5 units at $240 \mathrm{~nm}$. Pe roxidase, 1 unit = change of absorbance $\mathrm{min}^{-1}$ at $430 \mathrm{~nm}$.

Poly phenol Oxidase, 1 unit = amount of enzyme which trans forms 1 micromole of dihyd ric phenol to quinine.

Level of organic constituents in Averrhoa carambola Linn

\begin{tabular}{|ll|l|}
\hline & $\begin{array}{l}\text { Unripe } \\
\text { fruits }\end{array}$ & $\begin{array}{l}\text { Ripe } \\
\text { fruits }\end{array}$ \\
\hline Reducing sugars (mg/g) & 3.15 & 5.25 \\
\hline $\begin{array}{l}\text { Total carbohydrates } \\
(\mathrm{mg} / \mathrm{g})\end{array}$ & 65.36 & 110.25 \\
\hline Starch $(\mathrm{mg} / \mathrm{g})$ & 12.54 & 9.56 \\
\hline Protiens $(\mathrm{mg} / \mathrm{g})$ & 7.58 & 7.25 \\
\hline
\end{tabular}

\section{Conclusion:-}

Catalase, peroxidase, polyphenol oxidase, ascorbic acid, polyphenol activities were found to be maximal in the ripe ned fruits.

Catalase is the hamoprotein \& catalyses the decomposition of $\mathrm{H} 2 \mathrm{O} 2$ to water and $\mathrm{OH}$. Catalase involved in free radical scavenging mechanism on lipid peroxidation (Chander \& Kapoor N.K, 1990).

Peroxidase can be regarded as the enzyme having three types of enzyme activities, namely IAA oxidases, polyphenol oxidase \& peroxidase. The enzyme catalyses the oxidation of a wide variety of electron donors with the help of $\mathrm{H} 2 \mathrm{O} 2$

And the re by scavengers the endogenous $\mathrm{H} 2 \mathrm{O} 2$ (Mazumdar A, Adak S, Chatte rjee R and Banerjee R.K, 1997).

The fruit is with significant amount of ascorbic acid which increases on ripening, when green the fruits are astringent, but due to ample amount of ascorbic acid fruits on ripening, develop a sweetish acid taste. Due to Vit C fruits are often used for making refreshing drink and for cleaning metal surfaces especially for removing rust stains.

Ascorbic acid is used to protect a diversity of crops including beans, lettuce from leaf injury caused by air pollutants (Freebairn and Taylor, 1960). Ascorbic acid found to be less effe ctive in a nickel-N dibutyl dithio carbamate in protecting bean plants (Dass and Weaver, 1968). The ascorbic acid is an important water soluble antioxidant and plays a significant role in maintaining the water soluble oxidation reduction potential in human tissue (Halliwell and Kutsky 1973).

Due to ascorbic acid and high content of carbohydrates fruits have delicious taste and are made into stews, curries, pudd ings and tarts. The slight unripe ones are made into jams, jellies, pickles and preserves. The antioxidant activity of polyphenols are reported in human diet. (Faller, A.L.K. and Fialho, E. (2009).

Polyphe nols are reported to be promising in treatment of lymphocyte of malignancy. Phenolic compounds have also been shown to exhibits cellular defense mechanism in antherogenesis and cancer (Dacker, 1977). The role of carbohydrates and proteins is well documented in human diet.

\section{References :}

Luck.H. 1974, In methods in enzymatic analysis 2 (Ed Bergmeyer) Academic press New York P885.

.Mitra R. 1997. Ethnobotany in India : Retrospect and prospect, In : contribution to Indian ethnobotany, Third revised edition, Scientific publishers India, Jodhpur, Pre face.

Castillo, J.J. O.Benavente-Garcia, J. Lorente, M. Alcaraz, A. Redondo, O.A Ortun,. And J.A. Del Rio, (2000). Antioxidant activity and radio protective effects against chromosomal damage induced in vivo by X-rays of flavan-3-ols (procyanidins) from grape seeds (Vitis vinifera): comparative study versus other phenolic and organic compounds. J Agric Food Chem. 48: 1738-1745.

Chander R and Kapoor, N.K. 1990.Hepatic supe roxiode dismutase, catalase and lipid

Dass, H.C and G.M. Weaver 1968. Can J. Plant. Sci. 48:569-574 Exp. Biol, 28 : 195-197.

Faller, A.L.K.; Fialho, E. The antioxidant capacity and polyphenol content of organic and conventional retail vegetables after domestic cooking. Food Res. Int. 2009, 42, 210-215.

Freebrain, H.T and O.C.Taylor, 1960. Proc. Amer Soc.Hort.Sci.76:693-699.

Gulcin, 2006b. Antioxidant activity of caffeic acid (3,4-dihydroxycinnamic acid). Toxicology 217: 213-220. 
Halliwell B (1994). Free radicals, antioxidants, and human disease: curiosity, cause, or consequence Lancet. 344: 721-724.

Lowry, O.H, Rosenbrough, N.J Farr, A.L and R and all, R.J, 1951. Protien measurement with Folin Phenol reagent J.Biol. Chem. 193:265-27

M.L Lopez-Amoros,. T. Hernandez, and I. Estrella, (2006). Effect of ge rmination on legume phenolic compounds and their antioxidant activity. J. Food Comp Anal. 19: 277-283.

Mazumdar A, Aak S. Chatterhee R and Bannerjee R.K 1997.hanism based inactivation of lacrimal gland peroxidase by phenyl hydrazine : A suicidal substrate to probe the active site. Biochem.

Minakshi Mahajana and Monali Patil (2004). Antioxidant activity and organic constituents of curry leaf tree ( Murraya Koenigii Linn). Assian Jr. of Microbiol. Biotech.Env. Sc. Vol. 2 No. (2) 2004. 323-324.

Nadkarni G.D., Mitra A.G, Deshpande U.R and Pahiya D.N, 1991.antioxidant defence and lipid peroxidation in Vitamin D deprived rats Ind.J. Biochem. Biophys $28: 224-225$.
Nelson, N.C 1944. A photometric adoption of the somogyi method for determination of glucose, peroxidation products in mastomystalensis infected with plasmodium berghai, Ind.J. J, Biol.Chem. 153 : 375-380

Ray S and Chakrabarti P. 1999. Alterea Lipid peroxidation and antioxidant pote ntial in human ute re ine tumors Ind.J. Exp.Biol.37 : 439-443.

Sadasivan, S and Manickam, 1996.In Biochemical methods 2 (rd). New age International publishers. New Delhi \& Tamil Nadu Agricultural University, Coimbatore.

Sadasivan, $\mathrm{S}$ and Theymoli Balasubraminan 1987. In practical manual in Biochemistry Tamil Nadu Agricultural University Coimbatore P14.

Sara Jelodarian, Abdolrasoul Haghir Ebrahimabadi, Ahmad Khalighi, Hossain Batooli. (2012) Evaluation of antioxid ant activity of Malus domestica fruit extract from Kashan area. Avice nna Journal of Phytomedicine, Vol. 2, No. 3, Summer 2012, 139-145

Vidya sekharan P and Durairaj, P. 1973. Shot hole syndrome in mango Indian Phytopathology $26: 49-55$. 